Article

\title{
Sustainable Inventory Management in Supply Chains: Trends and Further Research
}

\author{
Pablo Becerra ${ }^{1,2}$, Josefa Mula ${ }^{1}(\mathbb{D})$ and Raquel Sanchis ${ }^{1, *}$ \\ 1 Research Centre on Production Management and Engineering (CIGIP), Universitat Politècnica de València, \\ Alarcón 1, 03801 Alcoy, Spain; pbecerr@doctor.upv.es or pablo.becerra@uda.cl (P.B.); fmula@cigip.upv.es (J.M.) \\ 2 Department of Industry and Business, Universidad de Atacama, Copiapó 1532297, Chile \\ * Correspondence: rsanchis@cigip.upv.es
}

Citation: Becerra, P.; Mula, J.; Sanchis, R. Sustainable Inventory Management in Supply Chains: Trends and Further Research. Sustainability 2022, 14, 2613. https:// doi.org/10.3390/su14052613

Academic Editor: Georges Zaccour

Received: 28 January 2022

Accepted: 21 February 2022

Published: 24 February 2022

Publisher's Note: MDPI stays neutral with regard to jurisdictional claims in published maps and institutional affiliations.

Copyright: (C) 2022 by the authors. Licensee MDPI, Basel, Switzerland. This article is an open access article distributed under the terms and conditions of the Creative Commons Attribution (CC BY) license (https:// creativecommons.org/licenses/by/ $4.0 /)$.

\begin{abstract}
This article presents an overview of the models applied to sustainable inventory management in supply chains and a roadmap for new research. It aims to address the lack of understanding of how sustainability is being incorporated into quantitative inventory management models in the supply chain context. The study is based on a classification of the reviewed literature according to the following criteria: supply chain structure, environmental approach, problem type, modeling, and solution approach. As a result, 36 articles were analyzed and classified. The main findings show that studies that incorporate social sustainability into inventory management along supply chains are lacking, while environmental studies are a growing research area. Uncertainty issues also need to be incorporated into sustainable inventory management models. Another important result of this study is the definition of a roadmap with trends and future research guidelines. The identified future research guidelines include incorporating decisions that can help to improve economic, environmental, and social sustainability. Thus, future studies should focus on both following quantitative models that incorporate inventory decisions integrally with transportation and location decisions, and more complex models, and employing new algorithms and heuristics to solve them.
\end{abstract}

Keywords: inventory management; sustainability; supply chain

\section{Introduction}

The economic growth process based on process technology began after the first industrial revolution in the second half of the 18th century. The industrial revolution unleashed not only an economic, scientific, and technical boom but also an intensive, extensive and irrational use of natural resources to search for accelerated economic growth models that occurred when it began. Environmental aspects are very important for reducing the global warming effect associated with increasing $\mathrm{CO}_{2}$ emission rates as a result of globalized industrialization, goods storage, and transportation. According to Arikan et al. [1], the storage and transport of goods are considered the most important causes of environmental hazards in the logistics chain and are the main reasons for $\mathrm{CO}_{2}$ emissions.

Sustainable inventory management (SIM) relates to decisions on inventory, warehousing, and material handling by focusing on reducing environmental and social impacts without affecting profitability [2]. Incorporating location and transportation issues into modeling could lead to sustainable supply chains (SCs). Recent research has highlighted the need to include factors other than traditional inventory models to design sustainable inventory systems by integrating the factors affecting the environmental impact into the traditional economic order quantity (EOQ) model [3]. It is crucial to develop a SIM model that takes into account income increase and waste prevention and reduces energy costs [4]. Decisions on lead times, replenishment quantities, and storage facilities influence emissions and costs [5].

Very few review articles have focused on the collection and analysis of inventory models that include sustainability, which is the main motivation of this paper. Pattnaik et al. [6] 
present a systematic literature review about integrating sustainability issues into inventory management models, specifically those topics that consider environmental criteria such as greenhouse gas (GHG) emissions, ecological quality controls, unsold inventory, and fixed carbon costs. Hence these authors mainly contribute decision-makers to identify the environmental and social factors that could be included in inventory models to encourage sustainable development. A comprehensive literature review of studies on inventory routing problems that incorporate sustainability aspects is provided by Malladi and Sowlati [7]. Chan et al. [8] classify the mathematical problems that deal with the management of sustainable manufacturing systems by classifying selected articles into three categories according to the main manufacturing system elements: production planning and control; inventory management and control; and manufacturing network design. Finally, a more extensive review that focuses on green SC quantitative models for SIM is found in Becerra et al. [9]. They identify and classify specific criteria related to modeling sustainable inventory problems in terms of purpose, application context, SC structure, decision level, shared information, inventory policies, inventory modeling, sustainability, circular economy and green modeling approaches, modeling approach, solution approaches, and software tools. Yadav et al. [10] identify the research gaps and advantages of waste management, preservation technology, and setup cost reduction from an SC perspective with a smart manufacturing system for products with cross-price elasticity of demand.

In addition, the present study attempts to bridge the research gap of how sustainability should be integrated into quantitative SC inventory management models. Therefore, this article contributes to identifying research trends related to quantitative SIM models in SCs and, by doing so, to proposing a roadmap for future studies. These trends and further research works are based on the following classification criteria: environmental approach, problem type, SC structure, model approach, and solution approach. The literature review by [6] focuses on SIM models approached by quantitative methods (the modeling and solution approach) exclusively and in a supply-chain context by also considering the inventory problem, location, and routing problems.

Therefore, the aim of this study is twofold: (1) to offer an overview of the literature on SIM in SCs from an environmental perspective by identifying the type of problem, SC structure, model, and solution approach; (2) to propose a roadmap for future research lines based on the trends identified in this work according to the classification criteria. The posed research question is: what is the roadmap of trends and further research lines for SIM models in an SC?

The remainder of the paper is structured as follows. Section 2 describes the review methodology. Section 3 offers an overview of the literature on SIM in SCs. Section 4 presents the discussion and proposes a roadmap for further research. Finally, Section 5 includes the conclusions and further research from the study.

\section{Review Methodology}

In order to fulfill this overview objective, relevant literature was compiled after considering the scientific articles published in the journals indexed in Scopus and Web of Science (WoS). In order to answer the research question, the following keywords were used in combination: supply chain, supply network, sustainable, green, circular economy, environment, social, inventory management, quantitative method, mathematical programming, optimization, analytic models, simulation, and artificial intelligence. No time window is defined. According to these search criteria, WoS and Scopus, respectively, indicated 142 and 183 related scientific articles published from 2004 to 2021. These articles were selected based mainly on the defined exclusion criteria: papers not related to the principal research field, i.e., that do not include environmental aspects, case studies on specific sectors not related to SCs, nonquantitative models, among others; duplicated studies; conference reviews; articles that neither present potential future lines nor develop a model (see Table 1). The remaining 36 articles were analyzed and classified to learn trends and future research areas. The followed review methodology is found in Figure 1. 
Table 1. Search methodology and paper selection process.

\begin{tabular}{cc}
\hline Keyword Used & $\begin{array}{c}\text { (Supply Chain or Supply Network) and (Sustainab* or } \\
\text { Green or Circular Economy or Environment or Social) and } \\
\text { (Inventory Management) and (Quantitative Method or } \\
\text { Mathematical Programming or Optimization or Analytic } \\
\text { Models or Simulation or Artificial Intelligence) }\end{array}$ \\
\hline Scopus database & 183 articles \\
\hline Wos database & 142 articles \\
\hline $\begin{array}{c}\text { Total papers in the two databases excluding duplication, } \\
\text { conference reviews, not considering environmental aspects, } \\
\text { case studies on specific sectors not related to SCs or } \\
\text { nonquantitative models }\end{array}$ & 47 articles \\
\hline $\begin{array}{c}\text { Articles that present potential future lines or develop a } \\
\text { quantitative model }\end{array}$ & 36 articles
\end{tabular}

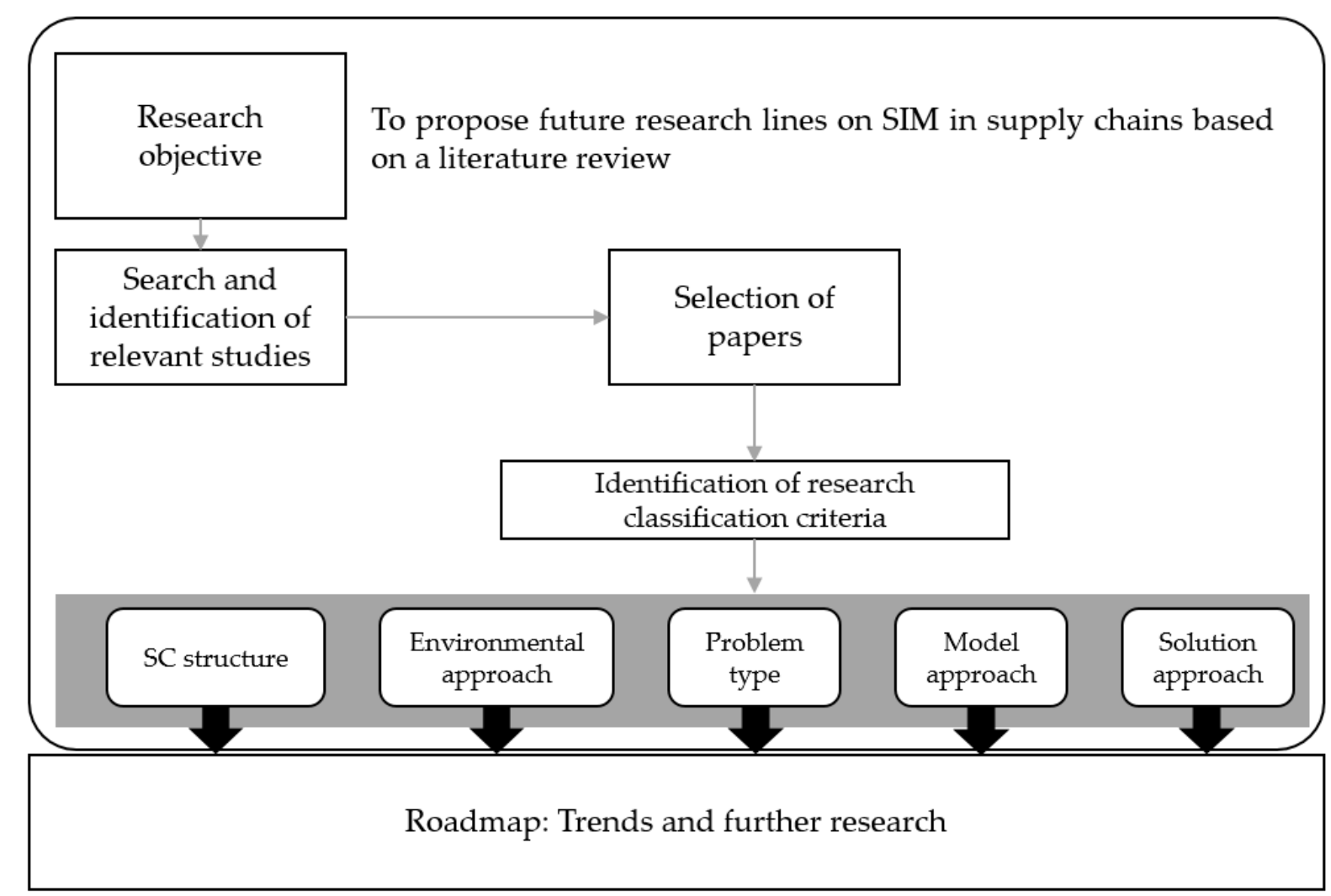

Figure 1. Review methodology.

Of the 36 selected papers, 25\% of the articles about SIM in SCs are published in three journals: International Journal of Production Economics, Computer Aided Chemical Engineering, and Journal of Cleaner Production. Appendix A.1. Distribution of Reviewed Publications per Journal presents the distribution of the reviewed publications per journal.

The number of publications per year (see Figure 2) reveals that researchers have recently paid attention to this research topic. Most of the research $(86.11 \%)$ has been conducted in the last 10 years, and over half the research papers $(61.11 \%)$ were published in the past 5 years. 


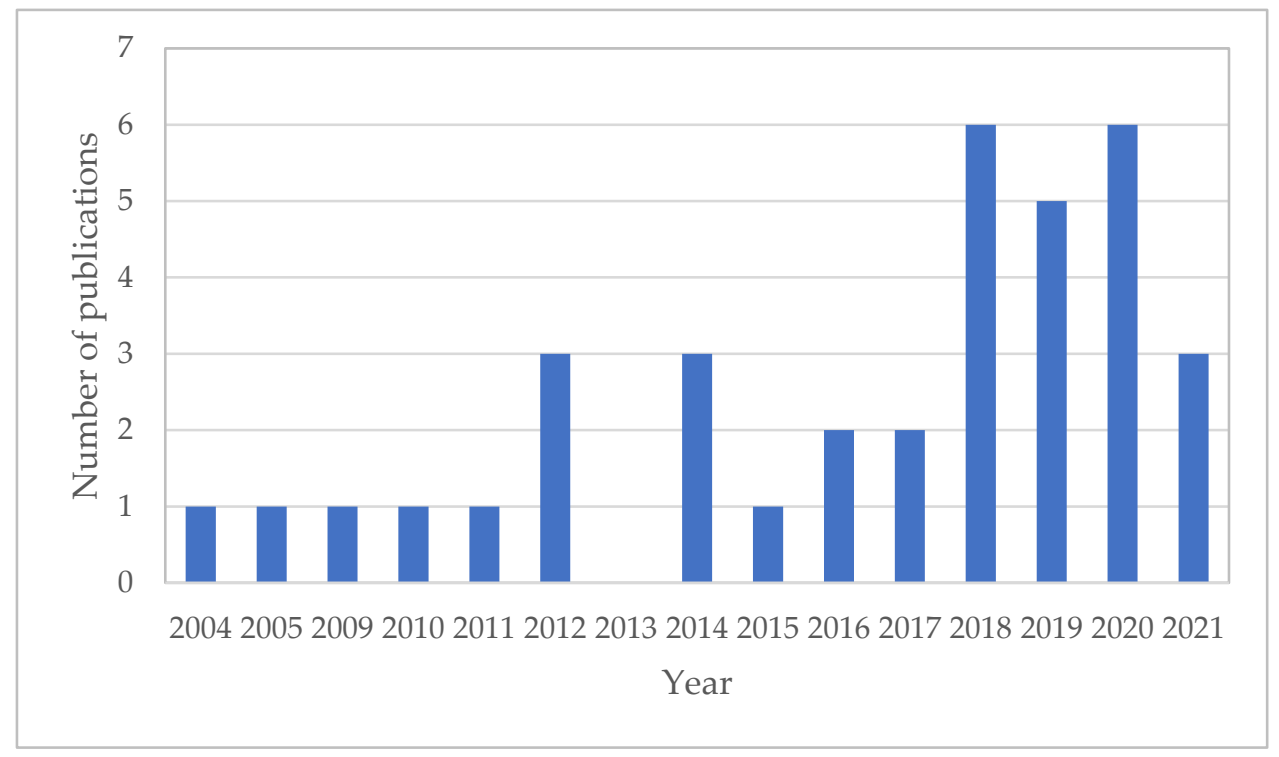

Figure 2. Number of publications per year.

\section{Literature Review}

The literature review focuses mostly on the main objective of the reviewed articles, and on the proposals of future research lines, by distinguishing the three sustainability aspects: economic (EC), environmental (EN), and social (S). The research methodologies addressed in the reviewed papers are classified according to (Dangayach and Deshmukh [11] and Malhotra and Grover [12]): (i) conceptual, basic or fundamental concepts; (ii) descriptive, an explanation or description and questions related to the addressed problem; (iii) empirical, where the study data are taken from existing databases, and from literature reviews, case studies and taxonomy or typology approaches; (iv) cross-sectional exploratory, with surveys at a given time; (v) longitudinal exploratory, also based on surveys in which data are collected at two different time points, or more, in the same organizations. Here, empirical proposals stand out; that is, those referring to mathematical programming and simulation models. Very few studies include a statistical analysis by exploratory crosssectional research, and only two studies select the proposed conceptual research, specifically by literature reviews. The details of the findings of this literature review are provided in Appendix A.2. Sustainability Aspects, Research Methodology, Objectives and Proposed Further Research per Article.

Table 2 presents an overview of how SIM in SCs has been studied. It includes the following classification criteria: SC structure: D (dyadic), SE (serial), C (convergent), DV (divergent), CJ (cojoined), N (network), CL (closed-loop), RL (reverse logistic); environmental approach: R1 (recycling), R2 (reusing), R3 (remanufacturing), R4 (renewable), R5 (repair), R6 (reduce); problem type: L (location), I (inventory), R (routing); model approach: MP (mathematical programming), S (simulation), R (regression), C (conceptual); solution approach: E (exact), H (heuristic), M (metaheuristic), ST (statistical) and SS (simulation software).

The SC structures proposed by [13] are extended in this work to include reverse logistics and closed-loop approaches because both correspond to $30 \%$ of the reviewed articles. These structures include product returns, which imply reusing, repairing, reconditioning, remanufacturing, and recycling materials, an efficacious reverse logistics network design that offers not only environmental benefits but also economic benefits in terms of reduced raw material acquisition, inventory management, and waste disposal [14].

When developing inventory models to consider sustainability by incorporating its three pillars, the $S$ aspect appears to be poorly studied because only nine of the reviewed articles incorporate it. For example, Battini et al. [3] apply "external costs" to jointly include the EN and S dimensions in delivery operations, warehousing, and waste disposal. 
Nativi et al. [15] propose a model that involves an $S$ approach for patients to gain equitable access to essential medicines. Ivanov [16] and Ganev et al. [17] agree about using the offer of jobs in the local economy to estimate the S impact. Dekker et al. [18] developed a simulation model to study the effect of changing order size on the selected performance measures by addressing the $S$ issue; for instance, it addressed the service level, amount of wasted food, and a product's average remaining life. By also taking social welfare as an objective in sustainability [19], Halat et al. [20] specifically develop a model to guarantee access to food and healthcare.

Table 2. Overview of SIM in SCs.

\begin{tabular}{|c|c|c|c|c|c|}
\hline Reference & $\begin{array}{c}\text { SC } \\
\text { Structure }\end{array}$ & $\begin{array}{c}\text { Environmental } \\
\text { Approach }\end{array}$ & $\begin{array}{l}\text { Problem } \\
\text { Type }\end{array}$ & $\begin{array}{c}\text { Model } \\
\text { Approach }\end{array}$ & $\begin{array}{l}\text { Solution } \\
\text { Approach }\end{array}$ \\
\hline Arikan et al. [1] & SE & R6 & I & $\mathrm{s}$ & SS \\
\hline Battini et al. [3] & $\mathrm{N}$ & R6 & I & EOQ & $\mathrm{H}$ \\
\hline Chen et al. [4] & $\mathrm{CJ}$ & R6 & I & MP & $\mathrm{M}$ \\
\hline Fichtinger et al. [5] & $\mathrm{U}$ & R6 & I & $\mathrm{S}$ & SS \\
\hline Ali et al. [14] & RL & R1, R2, R3 & I & MP & $\mathrm{E}$ \\
\hline Nativi and Lee [15] & RL & R1 & I & $\mathrm{R}$ & ST \\
\hline Ivanov [16] & $\mathrm{N}$ & R6 & $\mathrm{L}$ & MP & $\mathrm{E}$ \\
\hline Ganev et al. [17] & $\mathrm{N}$ & R4 & L-I-R & MP & $\mathrm{E}$ \\
\hline Dekker et al. [18] & $\mathrm{D}$ & R6 & I-R & $\mathrm{S}-\mathrm{C}$ & SS \\
\hline Tsolakis and Srai [19] & $\mathrm{U}$ & R4 & I & $\mathrm{S}$ & SS \\
\hline Halat and Hafezalkotob [20] & $\mathrm{CJ}$ & R6 & I & MP & $\mathrm{E}$ \\
\hline Al-Haidous et al. [21] & $\mathrm{N}$ & R6 & $\mathrm{I}-\mathrm{R}$ & MP & M \\
\hline Žic and Žic [22] & SE & R6 & I & $\mathrm{s}$ & SS \\
\hline Amer et al. [23] & $\mathrm{N}$ & R6 & $\mathrm{I}-\mathrm{R}$ & S & SS \\
\hline $\begin{array}{l}\text { Mohammadnazari and } \\
\text { Ghannadpour [24] }\end{array}$ & C & R6 & $\mathrm{I}-\mathrm{R}$ & MP & $\mathrm{E}$ \\
\hline Zhang et al. [25] & C & R6 & L-I-R & MP & E \\
\hline Sun et al. [26] & $\mathrm{N}$ & R6 & L-I-R & MP & $\mathrm{E}$ \\
\hline Ching et al. [27] & $\mathrm{D}$ & R6 & I & S & SS \\
\hline Paam et al. [28] & $\mathrm{D}$ & R6 & I & MP & $\mathrm{E}$ \\
\hline Wang et al. [29] & $\mathrm{CJ}$ & R6 & $\mathrm{I}-\mathrm{R}$ & MP & $\mathrm{M}$ \\
\hline Nikolopoulou and Ierapetritou [30] & $\mathrm{U}$ & R1, R2, R3, R4, R6 & L-I-R & MP-C & E-H \\
\hline Bostel et al. [31] & RL & R1, R2, R3, R5 & L-I-R & MP-S & E-H-SS \\
\hline Kuo [32] & CL & R3 & I & S & SS \\
\hline Calmon and Graves [33] & $\mathrm{CL}$ & R3, R5 & I & MP-S & M \\
\hline Guo et al. [34] & CL & $\mathrm{R} 2, \mathrm{R} 3$ & L-I & MP & M \\
\hline Tighazoui et al. [35] & RL & R3 & I-R & $\mathrm{S}$ & M \\
\hline Ross et al. [36] & CL & R2 & I & S-R & ST \\
\hline Yang et al. [37] & CL & $\mathrm{R} 2$ & I & MP & M \\
\hline Zhang et al. [38] & C & R4 & L-I-R & S & SS \\
\hline Yilmaz Balaman and Selim [39] & $\mathrm{CJ}$ & R4 & L-I-R & MP & $\mathrm{E}$ \\
\hline Pati et al. [40] & RL & R1 & $\mathrm{I}-\mathrm{R}$ & MP & $\mathrm{E}$ \\
\hline Ahmadini et al. [41] & SE & R6 & I & MP & E-H \\
\hline Rout et al. [42] & $\mathrm{D}$ & R6 & $\mathrm{I}-\mathrm{R}$ & MP & $\mathrm{H}$ \\
\hline Tavana et al. [43] & $\mathrm{N}$ & R6 & L-I-R & MP & $\mathrm{E}$ \\
\hline Ugarte et al. [44] & $\mathrm{D}$ & R6 & $\mathrm{I}-\mathrm{R}$ & $\mathrm{s}$ & SS \\
\hline Takeda et al. [45] & $\mathrm{D}$ & R6 & I & $S$ & SS \\
\hline
\end{tabular}


Environmental approaches have been widely studied. Here from the circular economy perspective, extending the options for value retention from the well-known reduce, reuse, and recycle policies to the 10R policies is suggested [46] by including the criteria proposed in this article. The most studied concept is "reduce" (R6) because it appears in 22 of the reviewed articles (see Figure 3) and is described to minimize GHG emissions $[1,5,18,20-24,42-44,47]$ and to reduce waste production rather than disposing of created waste [3,4,25-30,45]. Ahmadini et al. [41] incorporate both GHG emissions and waste disposal minimization. Another studied environmental aspect is "remanufacture", which involves products at the end of their life or them needing maintenance and being returned. Parts or components are refurbished to be used as new products [14,30-35]. The "Reuse" (R2) aspect is less studied than the others. However, it comes over as a relevant aspect because it is often studied along with remanufacturing processes by considering return items that can be directly reused without them having to undergo major operations $[14,30,31,34,36,37]$.

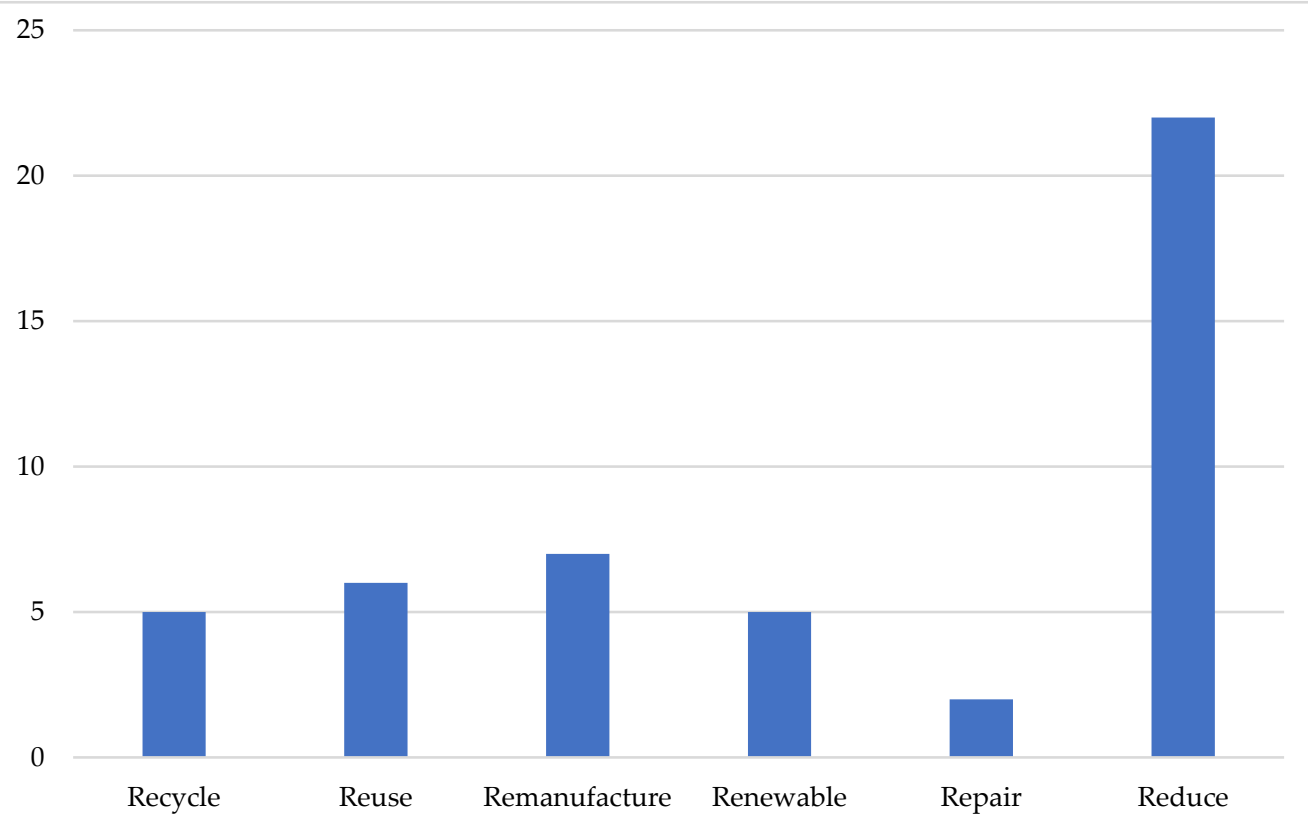

Figure 3. Number of publications per environmental approach.

The reviewed literature identified three problem types; location, inventory, and routing. They appear as individual problems or as combinations of two or three. Only one article includes the location problem in a review, that of Ivanov [16], who determines the optimum location of a bioethanol plant. In Guo et al. [24], an optimal solution to the locationinventory problem is developed to define the location and number of orders placed annually in a CL SC by considering sales on the primary and secondary markets for new and used products, respectively. Only one article presents a model that solves an inventoryproduction problem; Ahmadini et al. [41] consider that the production process contributes immensely to global warming. Eight articles solve the location-inventory-routing problem. This problem type addresses the relevance of coordinating location decisions, inventory management, and vehicle routing, such as selecting the distribution center's location, allocating customers for distribution, transportation routing of vehicles, and inventory strategy formulation $[17,25,26,30,31,38,39,43]$.

Of all the available model approaches, mathematical programming models are the most widely used to solve the aforementioned problems $(66.67 \%)$. Figure 4 particularly depicts: mixed-integer linear programming with six single objective cases $[16,17,20,24,26,28]$; multi-objective models [21,42]; multi-objective with fuzzy goal programming [39,43]; fuzzy 
multi-objective linear programming [14]; a multi-objective fractional programming model by Ahmadini et al. [41]; linear programming with one case [40]; sustainable EOQ developed by Battini et al. [3]; a constrained programming model overcome by Zhang et al. [25]; a stochastic optimization problem [33]; a Markov decision process [37]; mixed-integer nonlinear programming [34]; two integer programming models [4,29]. Simulation models are also widespread (33.33\%). Bostel et al. [31] and Nikolopoulou et al. [30] examine both simulation and mathematical programming models. Simulation models offer two main approaches: discrete-event simulation $[1,5,18,22,23,32,35,36,38,44,45]$ and system dynamics models [19,27]. Dekker et al. [18] and Nikolopoulou and Ierapetritou [30] apply a conceptual model to supplement their studies. Two regression models appear: one by Ross et al. [36] that describes a hybrid simulation-regression model and a regression model for the insight generation of managerial decisions by [15].

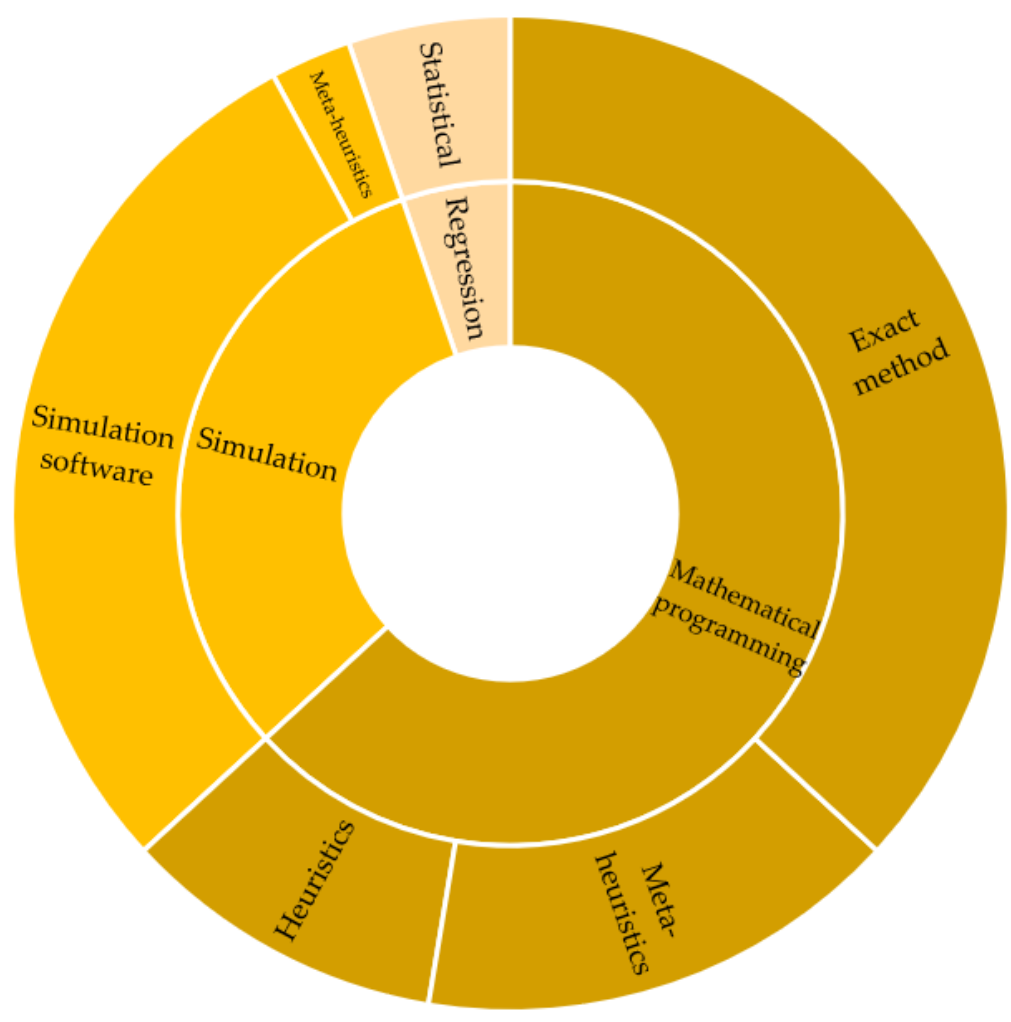

Figure 4. Distribution of publications per model and solution approach.

Solution approaches are closely related to the modeling approach. Thus, mathematical programming problems are solved by exact methods (58.33\%), heuristics $(16.67 \%)$, and metaheuristics $(25 \%)$. Otherwise, simulation models are modeled and solved mostly by simulation software (91.67\%). Tighazoui et al. [35] use metaheuristics to overcome their simulation problem. Ross et al. [36] and Nativi and Lee [15] apply a statistical approach to develop their multilinear regression models.

Finally, regarding the distribution of the articles reviewed in the different industrial sectors, $25 \%$ do not define a specific sector, but $22 \%$ focus on consumer goods, $14 \%$ on the energy sector, $8 \%$ on transport, and $8 \%$ on electrical and electronic devices. The rest are distributed in the different sectors, as shown in more detail in Figure 5. 


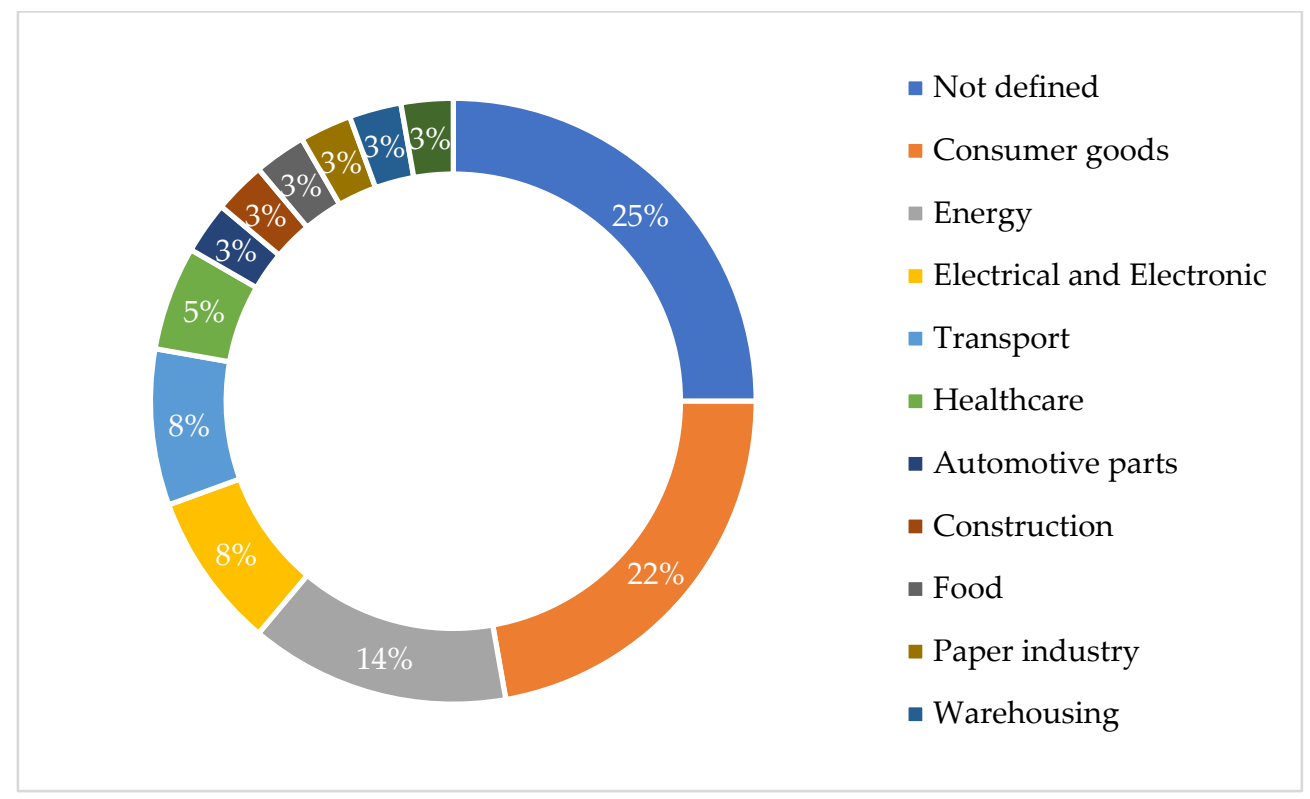

Figure 5. Distribution of publications per industrial sector of applications.

\section{Discussion}

Researchers show an interest in these designs thanks to their contributions to economic, social, and sustainable competitiveness, as indicated by [19]. The SC analysis can be reinforced in a closed network model that involves the integration of customized direct and reverse logistics for several problems. These structures need to include the amount and quality of return products, sources, and constraints $[6,7,34]$. Complexity in SC designs considers more levels with multiple products, and by including potential variability in different echelons $[1,4,14,25,26,28,35]$.

The main purpose is to reduce or minimize carbon emissions and to reduce waste production (see Figure 4). Green SC management is being increasingly contemplated by some countries and industries to develop SIM approaches that consider increased revenue while reducing waste and minimizing energy costs $[4,19,20,44]$. The impact of environmental government regulations on inventory costs should be studied [20,40]. The $S$ aspect of sustainability is poorly studied, which makes it a future research opportunity.

There is a growing need for models to integrate all relevant factors, such as inventory, production, disassembly activities, and transport for collection or distribution. Incorporating location, vehicle routing problems, and transport modes, and considering the variability of delivery times, loading and unloading times, and truck capacity may better reflect reality $[17,19,26,44,47]$. Extending inventory problems by contemplating location and transport issues is an opportunity to help to develop new models for SIM models in SCs; for instance, inventory costs, fixed and variable warehouse operating costs, the total cost at the destination, including production and delivery costs [5,31].

Models should deal with a more complex system that considers uncertainty by developing stochastic methods to contemplate demand and supply uncertainty, vehicle breakdowns, return products supply, or capacities $[14,28,30,31,35]$. For further research purposes, the development of integrated sustainable SC models should be enhanced to incorporate the whole sustainability dimension, including social aspects such as job satisfaction, worker welfare, and occupational safety $[5,21]$. The inclusion of multi-objective models is fundamental for practitioners and researchers, and the most widely applied approach to model such problems is mathematical programming, mainly with a single objective and solved by exact methods. So, developing multi-objective models that simultaneously incorporate the three sustainability pillars is essential [16,29,34]. A promising way to solve these problems is to develop and apply new algorithms and heuristics [26]. 
Finally, a roadmap (Figure 6) to identify trends and future directions in relation to each classification criterion is proposed.

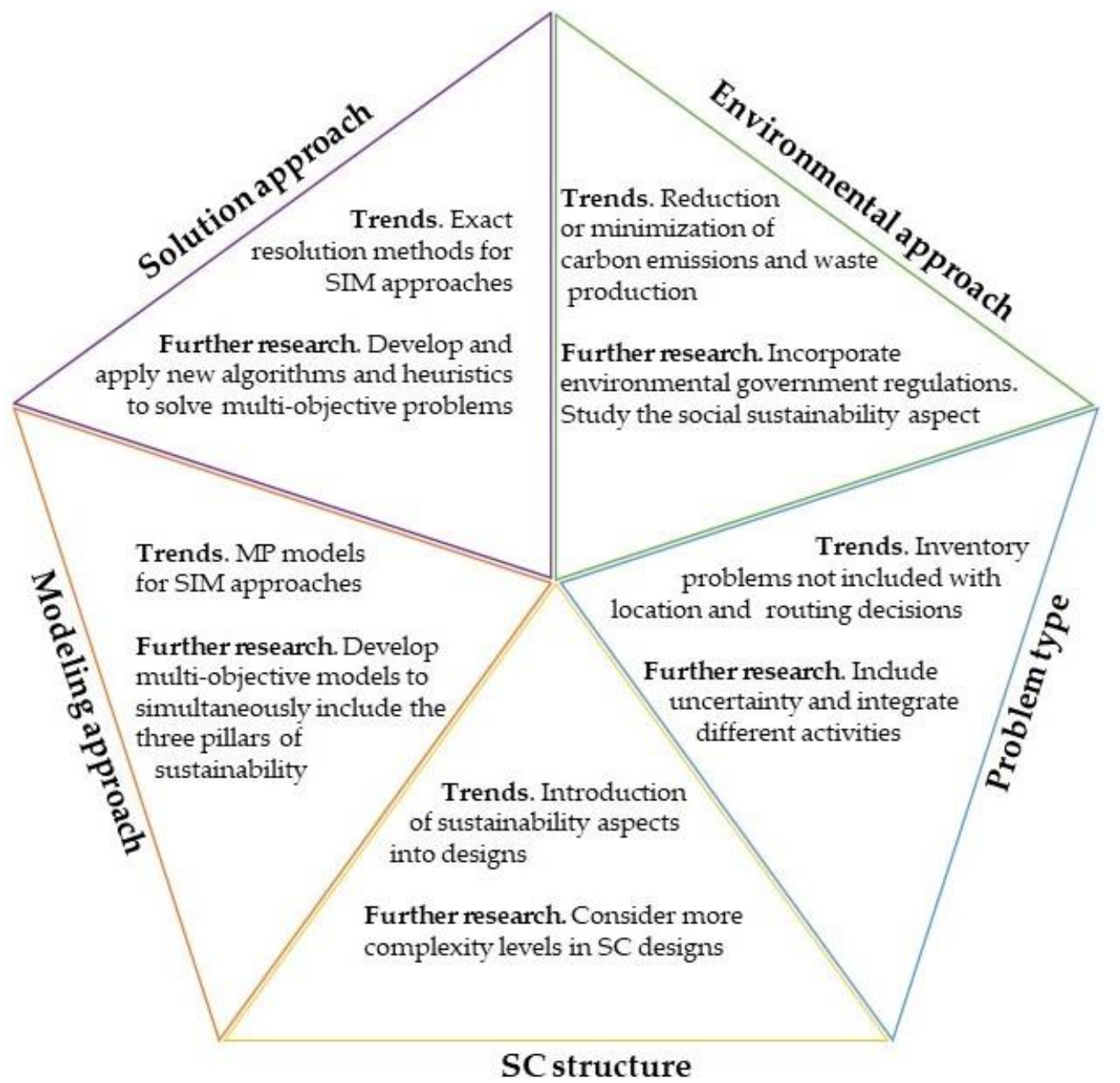

Figure 6. Roadmap of trends and further research lines.

First, regarding environmental aspects, the trend of studies focuses on reducing or minimizing GHG emissions and on minimizing waste generation in production activities. For future studies, we identify that SIM models should incorporate environmental government regulations about inventory costs and also incorporate the $\mathrm{S}$ sustainability issue. Second, inventory problems are considered in isolation regardless of facility location and transportation routing decisions. Therefore, we propose integrating inventory, production, disassembly activities, and location decisions into SIM models, as well as transport for the collection and distribution of returned products. It would also be desirable to consider the uncertainty about the amount and quality of returned products, sources, and constraints. Third, sustainability is introduced by designing the supply network mainly through reverse logistics and closed-loop SCs (CLSC). With this criterion, future research should consider more complexity levels in SC designs using multiproducts and the potential variability in different SC echelons. Fourth, the development of MP models, specifically single-objective models, is a trend in SIM modeling approaches. For further research, it is advisable to develop multi-objective models to simultaneously deal with the three sustainability pillars; EC, EN, and S. Finally, on MP models, the most widely used solution approaches are exact methods. For future models, we propose developing and applying new algorithms and heuristics to solve multi-objective SIM problems. 


\section{Conclusions}

This article provides an overview of the scientific literature on SIM models in the SC context. It is specifically oriented to identify, select and analyze the main studies addressing how sustainability is being managed by SCs through quantitative inventory management models. The 36 reviewed articles are categorized according to the subsequent classification criteria: SC structure, environmental approach, problem type, modeling approach, and solution approach.

From the reviewed literature and the five classification criteria, the main findings reveal that almost one-third of the studies introduce sustainability aspects into designs by incorporating reverse and closed-loop logistics, whereas the environmental approach is widely studied in the reviewed articles. Uncertainty considerations should also be included in stochastic and fuzzy inventory management models [48]. Additionally, the new results from this study can be proposed on a roadmap that contemplates the main trends and future research guidelines, based on the main limitations and future research proposals of the reviewed articles, to be addressed by SIM quantitative models (Figure 6).

The managerial insights of this roadmap are oriented to serve as an initial conceptual framework to support practitioners and researchers in articulating strategies and practices that develop and implement SIM quantitative models in SCs by, for instance, repairing and reworking defective items in local stores to maximize profits in a global SC [49].

It is worth noting that there are some limitations to this review. The consulted scientific databases were Scopus and WoS, which are constantly updated. The provided data are those collected at the time when this research was carried out. Here we review the literature published until January 2022. Despite following a systematic search process, some valuable papers may have been overlooked for this review. Models are considered in an SC context, which leaves out single-stage sustainable inventory models.

Finally, new forthcoming works are about building a high-level conceptual SIM framework based on this study and considering SC structures, sustainable inputs, quantitative models, inventory policies, and sustainability objectives, among other dimensions and elements. This conceptual framework should be the basis for novel quantitative models, such as multi-objective mathematical implementations to optimize these SIM models in an SC context in terms of EN, EC, and S factors. These new conceptual and quantitative SIM models should be applied to several real-world applications. Indeed, the authors are working to do so in the copper mining industry.

Author Contributions: The work was shared as follows: P.B. contributed with article conceptualization, methodology, data curation, formal analysis, investigation, visualization, writing original draft; J.M. and R.S. also contributed with conceptualization, supervision, resources, visualization, writing-review and editing. All the authors have read and agreed to the published version of the manuscript. All authors have read and agreed to the published version of the manuscript.

Funding: The research leading to these results received funding from Grant RTI2018-101344-B-I00 funded by MCIN/AEI/10.13039/501100011033 and by "ERDF A way of making Europe" and the "Industrial Production and Logistics Optimization in Industry 4.0" (i4OPT) (Ref. PROMETEO/2021/065) project funded by the Valencian Regional Government. It was also funded by the National Agency for Research and Development (ANID)/Scholarship Program/Doctorado Becas en el Extranjero/2020-72210174.

Institutional Review Board Statement: Not applicable.

Informed Consent Statement: Not applicable.

Conflicts of Interest: The authors declare no conflict of interest. 
Appendix A.

Appendix A.1. Distribution of Reviewed Publications Per Journal

\section{Number of publication per journal}

Environmental Science and Pollution Research Alexandria Engineering Journal Wireless Networks Waste Management

The International Journal of Advanced Manufacturing Technology Sustainability

Renewable Energy. An international journal.

Proceedings Industrial Engineering and Operations Management

Manufacturing \& service operations management Logistics Systems: Design and Optimization Journal of Purchasing \& Supply Management Journal of Combinatorial Optimization International Journal of Sustainable Engineering International Journal of Physical Distribution \& Logistics Management International Journal of Mathematics in Operational Research International Journal of Environmental Research and Public Health

International Journal of Business Performance Management IFAC-PapersOnLine Environment, Development and Sustainability Computers and Electronics in Agriculture Computers and Chemical Engineering Computers \& Industrial Engineering Proceedings Int. Conf. of Transportation Professionals Chemical Engineering Transactions Bulgarian Chemical Communications Advances in Science, Technology and Engineering Systems Journal Advances in Production Engineering \& Management Computer Aided Chemical Engineering Journal of Cleaner Production International Journal of Production Economics
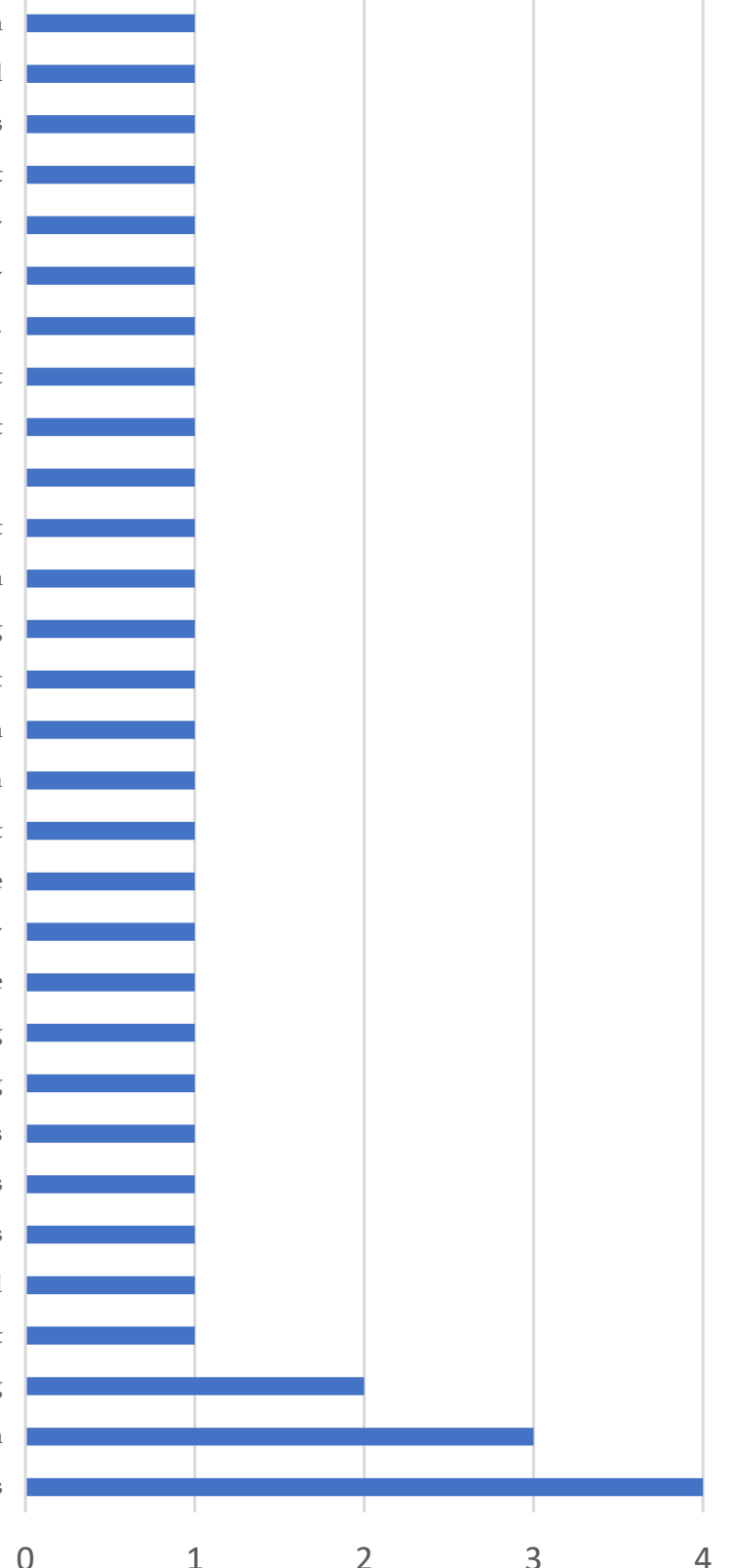

Figure A1. Distribution of reviewed publications per journal. 
Appendix A.2. Sustainability Aspects, Research Methodology, Objectives and Proposed Further Research Per Article

Table A1. Sustainability aspects, research methodology, objectives and proposed further research per article.

\begin{tabular}{|c|c|c|c|c|c|c|}
\hline \multirow{2}{*}{ Reference } & \multicolumn{3}{|c|}{ Sustainability Aspects } & \multirow{2}{*}{$\begin{array}{c}\text { Research } \\
\text { Methodology }\end{array}$} & \multirow{2}{*}{ Objective } & \multirow{2}{*}{ Proposed Further Research } \\
\hline & EC & EN & $S$ & & & \\
\hline Pati et al. [40] & $x$ & $x$ & & Empirical & $\begin{array}{l}\text { Formulate a linear analytical } \\
\text { model which minimises the total } \\
\text { reverse logistics costs for } \\
\text { multivariety recycled waste } \\
\text { reverse logistics systems } \\
\text { (RWRLS) subjected to constraints } \\
\text { that take into account various } \\
\text { internal and external factors that } \\
\text { affect RWRLS. }\end{array}$ & $\begin{array}{l}\text { Formulate a cost optimization } \\
\text { model that considers the impact } \\
\text { of various government } \\
\text { regulations on the } \\
\text { recycling industry. }\end{array}$ \\
\hline Bostel et al. [31] & $x$ & $x$ & & Conceptual & $\begin{array}{l}\text { Review the applications, case } \\
\text { studies, models and techniques } \\
\text { proposed for the design, } \\
\text { planning and optimization of } \\
\text { reverse logistics systems. }\end{array}$ & $\begin{array}{l}\text { There is a growing need for } \\
\text { models to integrate all relevant } \\
\text { factors, i.e., inventory } \\
\text { management, production or } \\
\text { disassembly activities, as well as } \\
\text { transport activities, for collection } \\
\text { or distribution planning. There is } \\
\text { also a need for specialized } \\
\text { models adapted to realistic } \\
\text { specific cases. Regarding } \\
\text { strategic models, the data of the } \\
\text { return flows and models should, } \\
\text { therefore, incorporate stochastic } \\
\text { features or be robust for the } \\
\text { uncertainty of the supply of } \\
\text { return products. }\end{array}$ \\
\hline
\end{tabular}

Determine with a simulation experiment what strategy is the most efficient one of the proposed strategies in the inventory management area by Dekker et al. [18] $\quad$ Empirical considering the use of temporary storage offered by intermodal transhipment points to position some stock of fast-moving consumer goods in advance of demand.

\begin{tabular}{clcl}
\hline Ross et al. [36] $\quad X \quad \begin{array}{c}\text { Exploratory } \\
\text { cross-sectional }\end{array}$ & $\begin{array}{c}\text { Develop managerial insights } \\
\text { related to the management and } \\
\text { repositioning of the empty } \\
\text { reusable container inventory. }\end{array}$ \\
\hline Kuo [32] & X & Empirical & $\begin{array}{c}\text { Simulate and construct a manu- } \\
\text { facturing/remanufacturing } \\
\text { model by means of different } \\
\text { inventory management strategies } \\
\text { and variables. }\end{array}$
\end{tabular}

Apply floating-stock requires batch production, a somewhat predictable demand (in volume terms), containerised transport and a standardised product mix.

Address the container supply risk issue at all three types of port operations. This approach would examine variations in container ability with a view to minimize variation in container overstock and shortage.

The lean principle, material requirement planning in remanufacturing and forecasting in remanufacturing could be used to revise this research model.

The satisfaction between customer and remanufacturer could also be studied. 
Table A1. Cont.

\begin{tabular}{|c|c|c|c|c|c|}
\hline \multirow{2}{*}{ Reference } & \multicolumn{3}{|c|}{ Sustainability Aspects } & \multirow{2}{*}{$\begin{array}{c}\text { Research } \\
\text { Methodology }\end{array}$} & \multirow{2}{*}{ Objective } \\
\hline & EC & EN & $\mathbf{S}$ & & \\
\hline $\begin{array}{c}\text { Nativi and Lee } \\
\text { [15] }\end{array}$ & $X$ & $X$ & & $\begin{array}{c}\text { Exploratory } \\
\text { cross-sectional }\end{array}$ & $\begin{array}{l}\text { Investigate how Radio Frequency } \\
\text { Identification } \\
\text { information-sharing can help SCs } \\
\text { that use reverse logistics to } \\
\text { increase environmental and } \\
\text { economic benefits through more } \\
\text { coordinated } \\
\text { inventory management. }\end{array}$ \\
\hline
\end{tabular}

Proposed Further Research

An adaptive information-sharing policy must be proposed to remain economically beneficial when drastic changes in the SC configuration occur. Study how the government's role affects

players' economic performance. Government regulations can also help to motivate manufacturers, suppliers and third-party collectors to increase returns, but it is necessary to identify how incentives or penalties are assigned to achieve the best system improvement.

Develop a simulation model for SC management to include the selection of the optimal biofuel facility location, logistics design, inventory management and information exchange.
Refine the model to incorporate data uncertainty and model uncertainty, and also include inventory holding costs.

$\begin{array}{llll}\text { Zhang et al. [38] } & \mathrm{X} & \mathrm{X} & \text { Empirical }\end{array}$

Review research on sustainable chemical processes and $\mathrm{SC}$, and Nikolopoulou and Ierapetritou [30]

$X \quad X \quad X$

X

Conceptual identify the emerging challenges and future opportunities in this area.

Develop stochastic methods capable of capturing uncertainty effects. Define an appropriate performance measure for the accurate and efficient assessment of network operations to devise new modeling systems and solution techniques for SCM.

Examine integrated methodologies by combining two sustainable approaches or more (e.g., inventory management, production planning, product recovery, etc.)

Consider more SC levels and include the potential variability at different echelons. Production lead time at the supplier site and the transportation time on road/rail

Analyze a serial inventory system through the indirect effect of transport lead time variability with the replenishment policy on

SCs economic and environmental performance.
Arikan et al. [1] X
X
Empirical

from the supplier to the port, and from the central warehouse to further stocking points and customers, are potential causes of variability and inefficiency in the SC. Moreover, study the consideration of different transportation modes and the combination in intermodal logistics networks.

Integrate either interval programming to deal with uncertain data or integer programming to plan the capacity expansion problem of disposal facilities, transportation load or inventory. Design a multiwaste, multi-echelon, multi-uncertainty SC of the waste management network. 
Table A1. Cont.

\begin{tabular}{|c|c|c|c|c|c|c|}
\hline \multirow{2}{*}{ Reference } & \multicolumn{3}{|c|}{ Sustainability Aspects } & \multirow{2}{*}{$\begin{array}{c}\text { Research } \\
\text { Methodology }\end{array}$} & \multirow{2}{*}{ Objective } & \multirow{2}{*}{ Proposed Further Research } \\
\hline & EC & EN & $\mathrm{S}$ & & & \\
\hline Battini et al. [3] & $X$ & $X$ & $X$ & Empirical & $\begin{array}{l}\text { Propose a new easy-to-use } \\
\text { theoretical model to calculate a } \\
\text { sustainable EOQ, called S-EOQ, } \\
\text { and study S-EOQ compared to } \\
\text { the traditional approach (EOQ). }\end{array}$ & $\begin{array}{l}\text { Study the trade-off between costs } \\
\text { and emissions by analyzing the } \\
\text { influence of changes in a set of } \\
\text { key parameters. Apply an } \\
\text { integrated point of view to the } \\
\text { sustainable lot sizing problem, in } \\
\text { which the whole SC is involved } \\
\text { in sharing costs (and not only } \\
\text { one firm). }\end{array}$ \\
\hline $\begin{array}{c}\text { Fichtinger et al. } \\
{[5]}\end{array}$ & $x$ & $X$ & & Empirical & $\begin{array}{l}\text { Build an integrated simulation } \\
\text { model to examine the interaction } \\
\text { between inventory and } \\
\text { warehouse management. } \\
\text { Highlight the key effects of } \\
\text { inventory management on } \\
\text { warehouse-related greenhouse } \\
\text { gas emissions. }\end{array}$ & $\begin{array}{l}\text { Consider variable and fixed costs of } \\
\text { operating warehouses in a joint } \\
\text { inventory and warehouse cost } \\
\text { optimization problem. Analyze the } \\
\text { integrated warehouse and inventory } \\
\text { management in a larger SC context } \\
\text { by contemplating the total landed } \\
\text { cost, including manufacturing and } \\
\text { transport costs. Work in a } \\
\text { sustainable warehouse management } \\
\text { by integrating economic, social and } \\
\text { environmental goals. Increase the } \\
\text { efficiency of inventory management } \\
\text { and warehousing processes to } \\
\text { reduce their environmental impact } \\
\text { and to contemplate worker welfare, } \\
\text { job satisfaction and } \\
\text { occupational safety. }\end{array}$ \\
\hline Ugarte et al. [44] & & $x$ & & Empirical & $\begin{array}{l}\text { Quantify the difference in } \\
\text { greenhouse gas emissions } \\
\text { between a traditional EOQ } \\
\text { inventory policy and each } \\
\text { lean-oriented inventory } \\
\text { management practice. }\end{array}$ & $\begin{array}{l}\text { Study fundamental impacts, such } \\
\text { as the water footprint of lean } \\
\text { practices, from an international } \\
\text { stand point. }\end{array}$ \\
\hline
\end{tabular}

Develop a decision model for the sustainable design of biomass based on renewable energy SCs and district heating systems (DHS) with thermal energy storages. The model integrates strategic decisions, such as

Y1lmaz Balaman
and Selim [39] $\quad \mathrm{X} \quad$ Empirical

location and capacity selection for energy plants, DHS, thermal storages and biomass storages, with tactical decisions related to biomass production, supply and transportation planning, inventory management and energy production.

Describe, model and optimize inventory in a reverse logistics

Calmon and Graves [33] $X$ system that supports warranty returns and replacements for a consumer electronic device.
Develop a model to handle bioenergy SC design problems in various regions with different types of feedstock and transportation modes. Include the additional case-specific constraints required by the problem.
Develop a system dynamics model to investigate inventory planning and control operations of crude sulfate turpentine as the source of renewable terpenoid feedstocks, and 'green' paracetamol as the commercial medication, to support the design of SC operations for the emerging bio-based chemicals market.
Extend the modeling and analysis to relax the assumption that the price at which refurbished devices can be sold in a side channel is nonincreasing.

Promote effective operations management research about 'green' medications and outline robust

policy-making interventions. 
Table A1. Cont.

\begin{tabular}{ccccc}
\hline Reference & Sustainability Aspects & $\begin{array}{c}\text { Research } \\
\text { Methodology }\end{array}$ & Objective \\
\cline { 2 - 4 } & EC & EN & S & Simulate different inventory \\
Takeda Berger \\
et al. [45]
\end{tabular}

$\begin{array}{llll}\text { Sun et al. [26] } & X & X & \text { Empirical }\end{array}$

Propose an optimization model to minimize the total cost formula for a location-inventory-routing problem by considering food waste and fuel consumption.

Investigate the new containers ordering decision and the production decision with reusable containers through a discrete-time Markov decision process (MDP).

Develop a mixed-integer nonlinear programming model to optimize the facility location, facility-customer assignment and inventory replenishment decisions simultaneously, and also design a novel self-adaptive differential evolution algorithm to efficiently solve this model.

Proposed Further Research

Develop a model that contemplates variability in transportation time, loading and unloading times and truck capacity. Explore the model's influence on the involved costs by quantifying the impact of lead time and service level.

Incorporate uncertainty into demand, production and harvesting parameters.

Study the effect of different transportation modes, or multimodal, on SC sustainability,

as well as the effect of distinct water transportation types of either container shipment or reefer shipment on performance.

Develop an efficient heuristic algorithm to handle middle-scale and large-scale instances to use multiple products and to vary shelf lifetimes for perishable products.

Enrich the model with more inventory decisions and necessary restrictions. Extend the model to a semi-Markov decision process that considers the randomness of delivery/production processes. Extend to a

location-inventory-routing problem by incorporating the vehicle routing problem.

Consider different assignments between hybrid

distribution-collection centers and customer zones in different markets.

Apply the system dynamics framework to model perishable inventory systems and to design policies that benefit the environment and the economy by reducing waste production and increasing the viability of the goods reaching customers.

Apply a Stackelberg game between the government and a multistage green SC (GSC), in which the government's goal is to maximize social welfare and that of the GSC is to minimize its cost.
Apply system dynamics to evaluate and improve policies in a wide variety of cases.

Consider complex inventory management assumptions, such as deteriorating products and delayed payment, during demand uncertainty. Engage the rewards-driven systems and maintenance scheduling concepts with GSCM. 
Table A1. Cont.

\begin{tabular}{|c|c|c|c|c|c|c|}
\hline \multirow{2}{*}{ Reference } & \multicolumn{3}{|c|}{ Sustainability Aspects } & \multirow{2}{*}{$\begin{array}{c}\text { Research } \\
\text { Methodology }\end{array}$} & \multirow{2}{*}{ Objective } & \multirow{2}{*}{ Proposed Further Research } \\
\hline & EC & EN & $\mathrm{S}$ & & & \\
\hline $\begin{array}{c}\text { Tighazoui et al. } \\
{[35]}\end{array}$ & $x$ & & & Empirical & $\begin{array}{l}\text { Determine the optimal capacities } \\
\text { of the manufacturing and } \\
\text { remanufacturing stocks, } \\
\text { purchasing warehouses, } \\
\text { transport vehicles, and the } \\
\text { optimal percentage of end-of-life } \\
\text { returned products. }\end{array}$ & $\begin{array}{l}\text { Model a more complex system } \\
\text { that considers a random demand, } \\
\text { vehicle breakdowns and several } \\
\text { cities to be satisfied. }\end{array}$ \\
\hline Paam et al. [28] & $x$ & $x$ & & Empirical & $\begin{array}{l}\text { Investigate the impact of } \\
\text { inventory management } \\
\text { optimization through a } \\
\text { mathematical programming } \\
\text { model on fruit loss, and } \\
\text { inventory and processing costs, } \\
\text { in apple SCs by proposing new } \\
\text { inventory policies about } \\
\text { high-tech storage } \\
\text { room configuration. }\end{array}$ & $\begin{array}{l}\text { Extend the problem to a } \\
\text { multiproduct food SC or other } \\
\text { fruit and vegetable industries in } \\
\text { other geographical locations. } \\
\text { Investigate the effects of storage } \\
\text { technology on apple prices and } \\
\text { sales of top-quality fruit at a } \\
\text { higher price than } \\
\text { medium-quality fruit. } \\
\text { Incorporate demand or supply } \\
\text { uncertainty, and integrated } \\
\text { decisions, such as harvest } \\
\text { inventory or } \\
\text { inventory-transportation and risk } \\
\text { analysis. }\end{array}$ \\
\hline Chen et al. [4] & $x$ & & & Empirical & $\begin{array}{l}\text { Determine efficiently the optimal } \\
\text { product image location, product } \\
\text { price, and procurement quantity } \\
\text { that maximize the profit. }\end{array}$ & $\begin{array}{l}\text { Incorporate loss of stockouts into } \\
\text { the model based on the health } \\
\text { care system. Focus on the } \\
\text { estimation of price and space } \\
\text { elasticity of various supplies. }\end{array}$ \\
\hline $\begin{array}{l}\text { Al-Haidous et al. } \\
\text { [21] }\end{array}$ & $x$ & $x$ & & Empirical & $\begin{array}{l}\text { Develop a multi-objective } \\
\text { mathematical model for shipping } \\
\text { fleet scheduling, routing and } \\
\text { delivery for sustainable liquified } \\
\text { natural gas SCc. The model } \\
\text { incorporates flexibility in delivery } \\
\text { times; inventory management } \\
\text { and berth availability constraints; } \\
\text { and fuel consumption and } \\
\text { carbon emissions. }\end{array}$ & $\begin{array}{l}\text { Consider multidischarges on the } \\
\text { same route, ship-to-ship transfer } \\
\text { operation and alternative } \\
\text { routings between Asia and } \\
\text { Europe. Capture all the } \\
\text { sustainability dimensions at } \\
\text { higher resolutions. }\end{array}$ \\
\hline $\begin{array}{l}\text { Mohammadnazari } \\
\text { and } \\
\text { Ghannadpour } \\
\text { [24] }\end{array}$ & $x$ & $x$ & $x$ & Empirical & $\begin{array}{l}\text { Present a mathematical } \\
\text { programming formulation to } \\
\text { solve the problem of ordering the } \\
\text { required amount to project site, } \\
\text { while taking into account an } \\
\text { ancillary warehouse. }\end{array}$ & $\begin{array}{l}\text { Integrate location decisions into } \\
\text { the model formulation to find the } \\
\text { best warehouse location. }\end{array}$ \\
\hline Ganev et al. [17] & $x$ & $x$ & $x$ & Empirical & $\begin{array}{l}\text { Propose a mixed integer linear } \\
\text { programming model to optimize } \\
\text { the strategic design of a } \\
\text { sustainable integrated } \\
\text { biodiesel/diesel } \\
\text { SC using first- and } \\
\text { second-generation bioresources } \\
\text { for biodiesel production, such as } \\
\text { sunflower and rapeseed, waste } \\
\text { cooking oil and animal fats, by } \\
\text { considering all the sustainability } \\
\text { aspects: economic, } \\
\text { environmental, social. }\end{array}$ & $\begin{array}{l}\text { Incorporate uncertainty into } \\
\text { demand, production and } \\
\text { harvesting parameters. }\end{array}$ \\
\hline
\end{tabular}


Table A1. Cont.

\begin{tabular}{|c|c|c|c|c|c|}
\hline \multirow{2}{*}{ Reference } & \multicolumn{3}{|c|}{ Sustainability Aspects } & \multirow{2}{*}{$\begin{array}{c}\text { Research } \\
\text { Methodology }\end{array}$} & \multirow{2}{*}{ Objective } \\
\hline & EC & EN & $\mathrm{S}$ & & \\
\hline Žic and Žic [22] & $x$ & $x$ & & Empirical & $\begin{array}{l}\text { Analyze correlation and } \\
\text { interdependencies among } \\
\text { inventory levels, costs and } \\
\text { greenhouse gas emissions from } \\
\text { replenishments within SC echelons } \\
\text { using simulation-based inventory } \\
\text { optimization conducted in } 4000 \\
\text { experiments by assuming the } \\
\text { conditions of: stochastic market } \\
\text { demand, }(R, S, S) \text { inventory policy, } \\
\text { target fill rates, predefined lead } \\
\text { times, closing days constraint. }\end{array}$ \\
\hline Wang et al. [29] & $X$ & & & Empirical & $\begin{array}{l}\text { Propose a practical integrated } \\
\text { scheduling model for a port-centric } \\
\text { SC considering the particularity of } \\
\text { neighboring-port manufacturing, } \\
\text { uncertain arrival delay and } \\
\text { departure time caused by variable } \\
\text { draft requirements and dynamic } \\
\text { tidal levels with a mathematical } \\
\text { optimization model that aims to } \\
\text { minimize the overall cost. }\end{array}$ \\
\hline
\end{tabular}

Proposed Further Research

Consider a multi-echelon inventory system with different inventory policies.
Consider multimode land transportation. Different transportation modes have distinct scheduling rules, and landside transport scheduling can have a nonnegligible impact on the overall results.

Incorporate uncertainty about the amount and quality of return

$\begin{array}{llll}\text { Ali et al. [14] } & \mathrm{X} & \mathrm{X} & \text { Empirical }\end{array}$

Formulate a multi-item

Ahmadini et al.

[41]

$x$

Empirical multi-objective inventory mode with back-ordered quantity incorporating green investment in order to save the environment
Design a multi-echelon reverse logistics network, and propose a mixed integer linear programming model that considers a number of facilities and product returns with different recovery options to minimize total expenses.

products, sources and constraints, and some constraints, such as capacity and demand, that can be considered fuzzy, as well as objective functions. It can be strengthened in a closed network model, which is the integration of both forward and reverse

logistics, and can be customized for different problems.

Incorporate continuous price and or price break in the items.

Furthermore, late delivery and shortages of items can be

considered as an extension of the proposed model. Further, deteriorating items with expiration duration could be possibly considered as an extension to this work.

Consider supplier's score through multi-criteria decision-making approaches from economic, circularity, and social perspectives. Is suggest developing an efficient meta-heuristic algorithm to solve large-size instances of this problem. programming model to solve the location-inventory-routing problems in green supply chain with low-carbon emissions under uncertainty.
Design a bi-objective model minimizing both total cost and overall emissions simultaneously subject to a well-built set of

Rout et al. [42] $\quad X \quad X \quad$ Empirical

constraints. The model focuses on obtaining a trade-off between cost and emissions, thereby determining the optimal production-shipment policy and a proper routing plan for the fleet of vehicles.
Extend the model in an uncertain environment, be it random or fuzzy.
Literature review of SIM quantitative models in an SC context
Propose new conceptual frameworks and optimization models for SIM in an SC context 


\section{References}

1. Arikan, E.; Fichtinger, J.; Ries, J.M. Impact of Transportation Lead-Time Variability on the Economic and Environmental Performance of Inventory Systems. Proc. Int. J. Prod. Econ. 2014, 157, 279-288. [CrossRef]

2. Tiwari, S.; Daryanto, Y.; Wee, H.M. Sustainable Inventory Management with Deteriorating and Imperfect Quality Items Considering Carbon Emission. J. Clean. Prod. 2018, 192, 281-292. [CrossRef]

3. Battini, D.; Persona, A.; Sgarbossa, F. A Sustainable EOQ Model: Theoretical Formulation and Applications. Int. J. Prod. Econ. 2014, 149, 145-153. [CrossRef]

4. Chen, Y.K.; Chiu, F.R.; Chang, Y.C. Implementing Green Supply Chain Management for Online Pharmacies through a Vadd Inventory Model. Int. J. Environ. Res. Public Health 2019, 16, 4454. [CrossRef] [PubMed]

5. Fichtinger, J.; Ries, J.M.; Grosse, E.H.; Baker, P. Assessing the Environmental Impact of Integrated Inventory and Warehouse Management. Int. J. Prod. Econ. 2015, 170, 717-729. [CrossRef]

6. Pattnaik, S.; Nayak, M.M.; Abbate, S.; Centobelli, P. Recent Trends in Sustainable Inventory Models: A Literature Review. Sustainability 2021, 13, 11756. [CrossRef]

7. Malladi, K.T.; Sowlati, T. Sustainability Aspects in Inventory Routing Problem: A Review of New Trends in the Literature. J. Clean. Prod. 2018, 197, 804-814. [CrossRef]

8. Chan, F.T.S.; Li, N.; Chung, S.H.; Saadat, M. Management of Sustainable Manufacturing Systems-a Review on Mathematical Problems. Int. J. Prod. Res. 2017, 55, 1210-1225. [CrossRef]

9. Becerra, P.; Mula, J.; Sanchis, R. Green Supply Chain Quantitative Models for Sustainable Inventory Management: A Review. J. Clean. Prod. 2021, 328, 129544. [CrossRef]

10. Yadav, D.; Kumari, R.; Kumar, N.; Sarkar, B. Reduction of Waste and Carbon Emission through the Selection of Items with Cross-Price Elasticity of Demand to Form a Sustainable Supply Chain with Preservation Technology. J. Clean. Prod. 2021, 297, 126298. [CrossRef]

11. Dangayach, G.S.; Deshmukh, S.G. Manufacturing Strategy. Int. J. Oper. Prod. Manag. 2001, 21, 884-932. [CrossRef]

12. Malhotra, M.K.; Grover, V. An Assessment of Survey Research in POM: From Constructs to Theory. J. Oper. Manag. 1998, 16, 407-425. [CrossRef]

13. George, J.; Madhusudanan Pillai, V. A Study of Factors Affecting Supply Chain Performance. In Proceedings of the Journal of Physics: Conference Series; Institute of Physics Publishing: Bristol, UK, 2019; Volume 1355.

14. Ali, S.S.; Paksoy, T.; Torğul, B.; Kaur, R. Reverse Logistics Optimization of an Industrial Air Conditioner Manufacturing Company for Designing Sustainable Supply Chain: A Fuzzy Hybrid Multi-Criteria Decision-Making Approach. Wirel. Netw. 2020, 26, 5759-5782. [CrossRef]

15. Nativi, J.J.; Lee, S. Impact of RFID Information-Sharing Strategies on a Decentralized Supply Chain with Reverse Logistics Operations. Int. J. Prod. Econ. 2012, 136, 366-377. [CrossRef]

16. Ivanov, B. Multi-Period Deterministic Model of Sustainable Integrated of Hybrid First and Second Generation Bioethanol Supply Chains for Synthesis and Renovation. Bulg. Chem. Commun. 2018, 50, 24-35.

17. Ganev, E.I.; Dzhelil, Y.R.; Ivanov, B.B.; Vaklieva-Bancheva, N.G.; Kirilova, E.G. Optimal Design of a Sustainable Integrated Biodiesel/Diesel Supply Chain Using First and Second Generations Bioresources. Chem. Eng. Trans. 2020, 81, 67-72. [CrossRef]

18. Dekker, R.; van Asperen, E.; Ochtman, G.; Kusters, W. Floating Stocks in FMCG Supply Chains: Using Intermodal Transport to Facilitate Advance Deployment. Int. J. Phys. Distrib. Logist. Manag. 2009, 39, 632-648. [CrossRef]

19. Tsolakis, N.; Srai, J.S. Inventory Planning and Control in 'Green' Pharmacies Supply Chains—A System Dynamics Modelling Perspective. In Computer Aided Chemical Engineering; Elsevier: Amsterdam, The Netherlands, 2017; Volume 40, pp. 1285-1290.

20. Halat, K.; Hafezalkotob, A. Modeling Carbon Regulation Policies in Inventory Decisions of a Multi-Stage Green Supply Chain: A Game Theory Approach. Comput. Ind. Eng. 2019, 128, 807-830. [CrossRef]

21. Al-Haidous, S.; Govindan, R.; Al-Ansari, T. Swarm Optimisation for Shipping Fleet Scheduling, Routing and Delivery in Sustainable Liquified Natural Gas (LNG) Supply Chain Models. Comput. Aided Chem. Eng. 2020, 48, 1225-1230. [CrossRef]

22. Žic, J.; Žic, S. Multi-Criteria Decision Making in Supply Chain Management Based on Inventory Levels, Environmental Impact and Costs. Adv. Prod. Eng. Manag. 2020, 15, 151-163. [CrossRef]

23. Amer, H.H.; Galal, N.M.; El-Kilany, K.S. A Simulation Study of Sustainable Agri-Food Supply Chain. In Proceedings of the International Conference on Industrial Engineering and Operations Management, Paris, France, 26-27 July 2018.

24. Mohammadnazari, Z.; Ghannadpour, S.F. Sustainable Construction Supply Chain Management with the Spotlight of Inventory Optimization under Uncertainty. Environ. Dev. Sustain. 2020, 23, 10937-10972. [CrossRef]

25. Zhang, Y.; Huang, G.H.; He, L. A Multi-Echelon Supply Chain Model for Municipal Solid Waste Management System. Waste Manag. 2014, 34, 553-561. [CrossRef] [PubMed]

26. Sun, Q.; Chien, S.; Hu, D.; Ma, B. Optimizing the Location-Inventory-Routing Problem for Perishable Products Considering Food Waste and Fuel Consumption. In Proceedings of the CICTP 2018: Intelligence, Connectivity, and Mobility-Proceedings of the 18th COTA International Conference of Transportation Professionals, Beijing, China, 5-8 July 2018.

27. Ching, P.L.; Mutuc, J.E.; Jose, J.A. Assessment of the Quality and Sustainability Implications of FIFO and LIFO Inventory Policies through System Dynamics. Adv. Sci. Technol. Eng. Syst. 2019, 4, 69-81. [CrossRef]

28. Paam, P.; Berretta, R.; Heydar, M.; García-Flores, R. The Impact of Inventory Management on Economic and Environmental Sustainability in the Apple Industry. Comput. Electron. Agric. 2019, 163, 104848. [CrossRef] 
29. Wang, X.; Rodrigues, V.S.; Demir, E. Managing Your Supply Chain Pantry: Food Waste Mitigation Through Inventory Control. IEEE Eng. Manag. Rev. 2019, 47, 97-102. [CrossRef]

30. Nikolopoulou, A.; Ierapetritou, M.G. Optimal Design of Sustainable Chemical Processes and Supply Chains: A Review. Comput. Chem. Eng. 2012, 44, 94-103. [CrossRef]

31. Bostel, N.; Dejax, P.; Lu, Z. The Design, Planning, and Optimization of Reverse Logistics Networks. In Logistics Systems: Design and Optimization; Springer: Boston, MA, USA, 2005; pp. 171-212.

32. Kuo, T.C. The Study of Production and Inventory Policy of Manufacturing/Remanufacturing Environment in a Closed-Loop Supply Chain. Int. J. Sustain. Eng. 2011, 4, 323-329. [CrossRef]

33. Calmon, A.P.; Graves, S.C. Inventory Management in a Consumer Electronics Closed-Loop Supply Chain. Manuf. Serv. Oper. Manag. 2017, 19, 568-585. [CrossRef]

34. Guo, H.; Li, C.; Zhang, Y.; Zhang, C.; Lu, M. A Location-Inventory Problem in a Closed-Loop Supply Chain with Secondary Market Consideration. Sustainability 2018, 10, 1891. [CrossRef]

35. Tighazoui, A.; Turki, S.; Sauvey, C.; Sauer, N. Optimal Design of a Manufacturing-Remanufacturing-Transport System within a Reverse Logistics Chain. Int. J. Adv. Manuf. Technol. 2019, 101, 1773-1791. [CrossRef]

36. Ross, A.D.; Jayaraman, V.; Rodrigues, A.; Mollenkopf, D.A. Repositioning of Reusable Containers in a Sustainable Global Supply Chain Environment. Int. J. Math. Oper. Res. 2010, 2, 178-204. [CrossRef]

37. Yang, T.; Fu, C.; Liu, X.; Pei, J.; Liu, L.; Pardalos, P.M. Closed-Loop Supply Chain Inventory Management with Recovery Information of Reusable Containers. J. Comb. Optim. 2018, 35, 266-292. [CrossRef]

38. Zhang, F.; Johnson, D.M.; Johnson, M.A. Development of a Simulation Model of Biomass Supply Chain for Biofuel Production. Renew. Energy 2012, 44, 380-391. [CrossRef]

39. Yılmaz-Balaman, Ş.; Selim, H. Sustainable Design of Renewable Energy Supply Chains Integrated with District Heating Systems: A Fuzzy Optimization Approach. J. Clean. Prod. 2016, 133, 863-885. [CrossRef]

40. Pati, R.K.; Vrat, P.; Kumar, P.; Pati, R.K.; Vrat, P.; Kumar, P. Cost Optimisation Model in Recycled Waste Reverse Logistics System Int. J. Bus. Perform. Manag. 2004, 6, 245-261. [CrossRef]

41. Ahmadini, A.A.H.; Modibbo, U.M.; Shaikh, A.A.; Ali, I. Multi-Objective Optimization Modelling of Sustainable Green Supply Chain in Inventory and Production Management. Alex. Eng. J. 2021, 60, 5129-5146. [CrossRef]

42. Rout, C.; Paul, A.; Kumar, R.S.; Chakraborty, D.; Goswami, A. Integrated Optimization of Inventory, Replenishment and Vehicle Routing for a Sustainable Supply Chain under Carbon Emission Regulations. J. Clean. Prod. 2021, 316, 128256. [CrossRef]

43. Tavana, M.; Tohidi, H.; Alimohammadi, M.; Lesansalmasi, R. A Location-Inventory-Routing Model for Green Supply Chains with Low-Carbon Emissions under Uncertainty. Environ. Sci. Pollut. Res. 2021, 28, 50636-50648. [CrossRef]

44. Ugarte, G.M.; Golden, J.S.; Dooley, K.J. Lean versus Green: The Impact of Lean Logistics on Greenhouse Gas Emissions in Consumer Goods Supply Chains. J. Purch. Supply Manag. 2016, 22, 98-109. [CrossRef]

45. Berger, S.L.T.; Tortorella, G.L.; Frazzon, E.M. Simulation-Based Analysis of Inventory Strategies in Lean Supply Chains. IFAC-Pap . 2018, 51, 1453-1458. [CrossRef]

46. Reike, D.; Vermeulen, W.J.V.; Witjes, S. The Circular Economy: New or Refurbished as CE 3.0?-Exploring Controversies in the Conceptualization of the Circular Economy through a Focus on History and Resource Value Retention Options. Resour. Conserv. Recycl. 2018, 135, 246-264. [CrossRef]

47. Ivanov, D. Supply Chain Simulation and Optimization with AnyLogistix, 5th ed.; Berlin School of Economics and Law: Berlin, Germany, 2021.

48. Mahapatra, A.S.; Soni, H.N.; Mahapatra, M.S.; Sarkar, B.; Majumder, S. A Continuous Review Production-Inventory System with a Variable Preparation Time in a Fuzzy Random Environment. Mathematics 2021, 9, 747. [CrossRef]

49. Ahmed, W.; Moazzam, M.; Sarkar, B.; Ur Rehman, S. Synergic Effect of Reworking for Imperfect Quality Items with the Integration of Multi-Period Delay-in-Payment and Partial Backordering in Global Supply Chains. Engineering 2021, 7, 260-271. [CrossRef] 